Article

\title{
Integrated Evaluation of Changing Water Resources in an Active Ecotourism Area: The Case of Puerto Princesa City, Palawan, Philippines
}

\author{
Mark Ace Dela Cruz ${ }^{1,2}$, Shinichiro Nakamura ${ }^{3, *(D)}$, Naota Hanasaki ${ }^{4}$ (D) and Julien Boulange 4 (D) \\ 1 Graduate School of Environment Study, Nagoya University, Nagoya 464-8603, Japan; \\ markacevdelacruz2014@gmail.com \\ 2 Palawan Council for Sustainable Development, Puerto Princesa 5300, Philippines \\ 3 Department of Civil Engineering, Nagoya University, Nagoya 464-8603, Japan \\ 4 Center for Global Environmental Research, National Institute for Environmental Studies, \\ Tsukuba 305-8506, Japan; hanasaki@nies.go.jp (N.H.); boulange.julien@nies.go.jp (J.B.) \\ * Correspondence: shinichiro@civil.nagoya-u.ac.jp
}

\section{check for}

updates

Citation: Dela Cruz, M.A.; Nakamura, S.; Hanasaki, N.; Boulange, J. Integrated Evaluation of Changing Water Resources in an Active Ecotourism Area: The Case of Puerto Princesa City, Palawan, Philippines. Sustainability 2021, 13, 4826. https://doi.org/10.3390/ su13094826

Academic Editor: Dariusz Wrzesiński and Leszek Sobkowiak

Received: 24 March 2021

Accepted: 21 April 2021

Published: 25 April 2021

Publisher's Note: MDPI stays neutral with regard to jurisdictional claims in published maps and institutional affiliations.

Copyright: (c) 2021 by the authors. Licensee MDPI, Basel, Switzerland. This article is an open access article distributed under the terms and conditions of the Creative Commons Attribution (CC BY) license (https:/ / creativecommons.org/licenses/by/ $4.0 /)$.

\begin{abstract}
Rapid urbanization, tourism, and climate change (CC) threaten water resource management in developing countries. Conventional water-planning tools cannot account for the changing effects of water disparity, climate risks, and environmental flow (EF) requirements. This paper proposes an alternative approach that applies stylized water-demand forecasting and predicting water availability from the perspectives of $\mathrm{CC}$, changing society, and EF, thereby providing managers with future scenarios of surface water sufficiency/deficiency in an active ecotourism area, namely, Puerto Princesa City, Philippines. We considered (1) scenarios of seasonal droughts to prepare for climate risks in the future and (2) scenarios of water availability that do not depend on groundwater supply, in which the projected water deficiency is frequent both annually and seasonally. The results of this case study showed that an additional water supply from the Montible Watershed to the city was projected to secure sufficient amounts of water to achieve surface-water sufficiency, which is consistent with the goals of both the municipality and the water company to reduce the dependency on groundwater. Moreover, significant infrastructure investment costs must be anticipated in Scenario 3. Our approach proves efficient in modeling water demand in regions with active tourism and hydrology and therefore has the potential for further analyses and application.
\end{abstract}

Keywords: water resources; climate change; tourism; environmental flow; future scenarios; Philippines

\section{Introduction}

In the Anthropocene, human activities have had tremendous impacts on local environments, and these activities have now manifested as global issues such as climate change. It is essential to consider human activities and climate change in water resource management [1-5]. While climate change leads to changes in freshwater ecosystems, changes in human water demands cause serious water stresses that have intensified in already water-stressed regions [6-8].

Tourism is an important industry in low-income countries and alters the consumption pattern of water in concerned areas $[9,10]$. The increase in water consumption caused by tourism is often not considered in water planning. Estimates suggest that $80-3500 \mathrm{~L}$ of water per tourist per overnight stay is consumed [11-13]. Although tourism can bring high economic benefits $[14,15]$, it has also negative impacts on the natural water environment. The overexploitation of water resources is particularly sensitive in coastal and island destinations [16,17]. Overuse of water and ignoring environmental flow (EF) requirements cause ecological degradation in many parts of the world. For example, the Australian 
government has reallocated water to the environment at a substantial expense to mitigate the significant degradation suffered by the Murray-Darling Basin [18]. Maintenance of EF requirements should also be viewed as a measure of sustainability in water resource management and considered in water supply planning and implementation [19]. Sociohydrological changes and their impacts on the natural environment must be comprehensively considered and evaluated to achieve sustainable development, especially in areas that mainly rely on income from tourism.

This study aims to fill the research gap by integrating climate-change-induced hydrological processes, changes in the consumption of water for domestic and commercial purposes, and the environment for sustainable surface-water development in an active site for ecotourism. We consider multiple water-demand scenarios that account for the influence of tourists, local conditions, and water supply scenarios to provide options for the sustainable exploitation of surface-water sources under the influence of climate change. We highlight the adequacy of surface water resources to provide insights on surface-water development in the study region.

\section{Study Region}

In the Philippines, tourism accounts for $8.6 \%$ of the country's gross domestic product (GDP) [20]. Ecotourism plays a significant role in providing livelihood opportunities and serves as a tool for conservation in the Philippines. The study area, Puerto Princesa City (PPC) in Palawan Island (Figure 1), is one of the major ecotourism destinations in the country, where tourist arrivals and the population are increasing each year (Figure 2). Despite the sudden increase in tourist arrivals since 2009, the assumptions for planning and designing water-supply systems have remained unchanged, thereby ignoring the changing water consumption patterns.

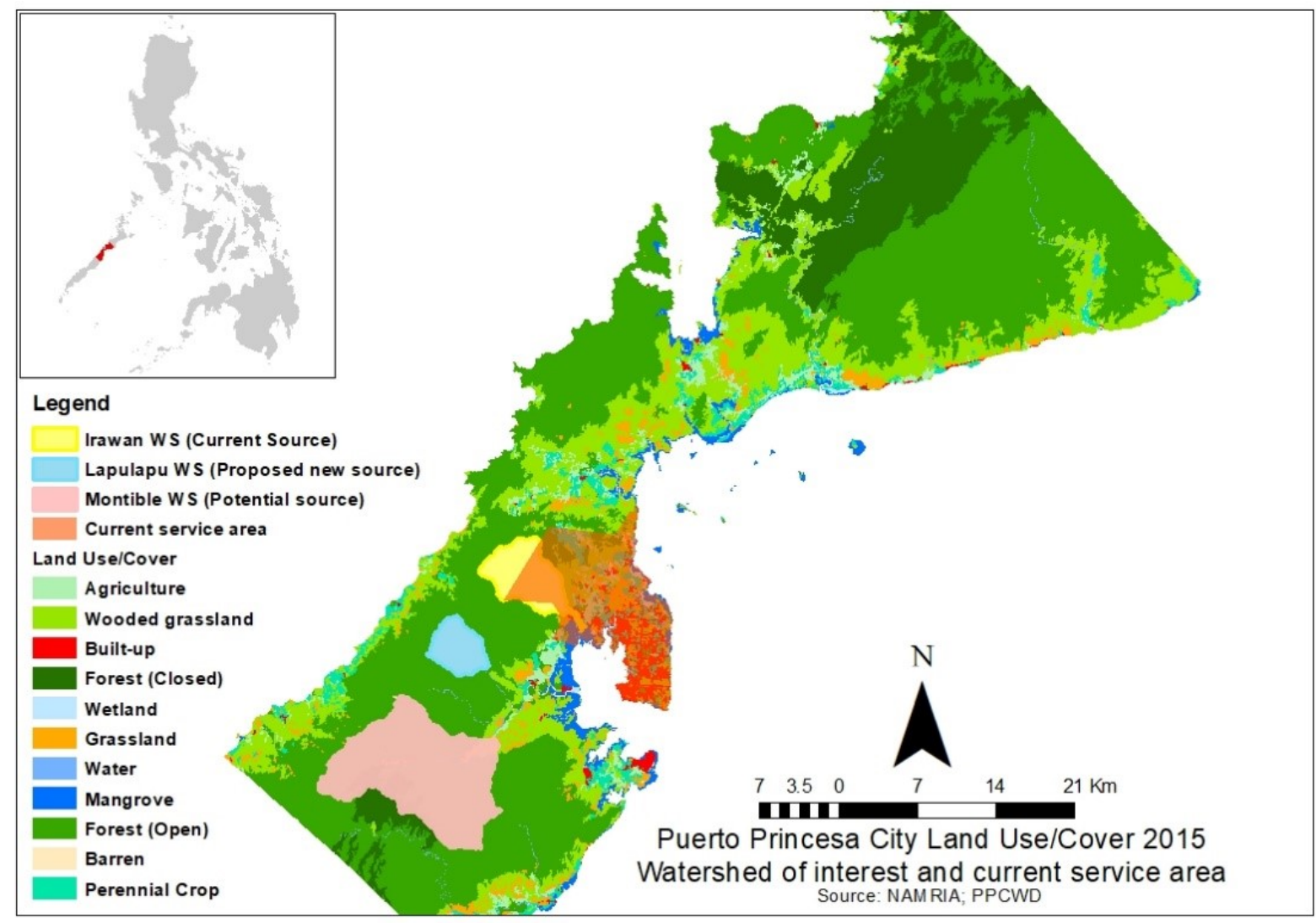

Figure 1. Land cover/use and target watershed of PPC in the Philippines. 


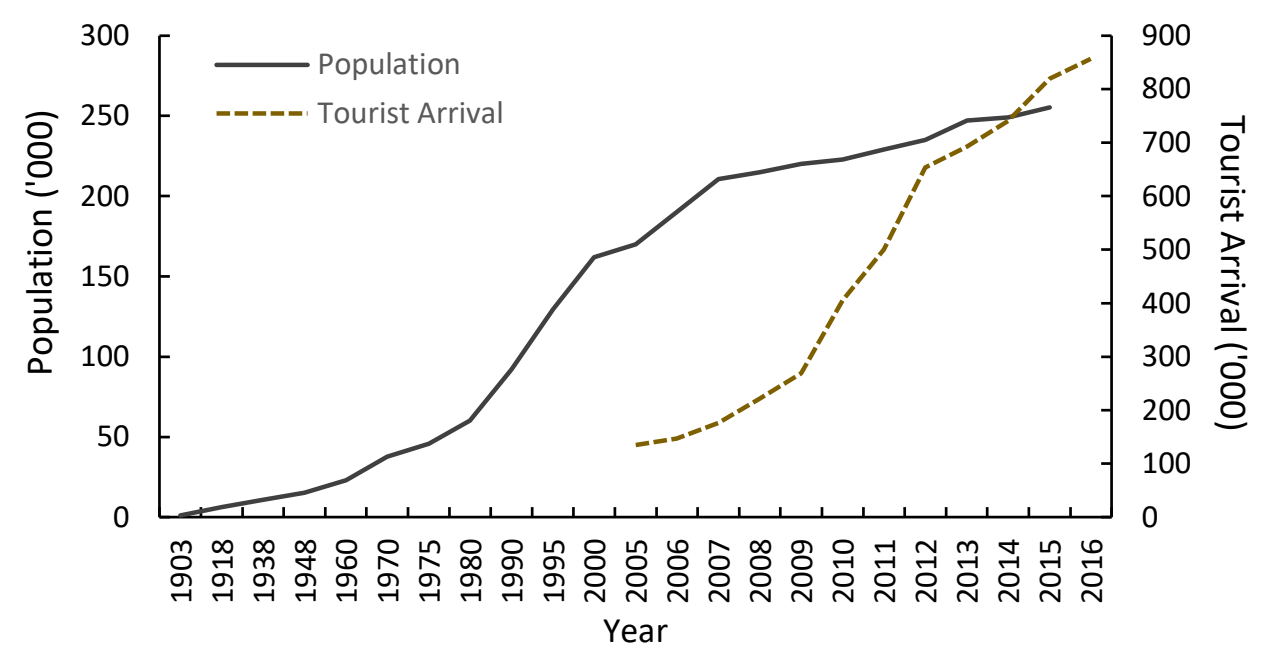

Figure 2. Population trend and tourist arrivals (source: PSA and City Tourism Office).

In 2011, a 25-million-liter day ${ }^{-1}$ (MLD)-capacity infiltration gallery (IG) was built upstream of the Irawan River (Figure 1) in addition to the 5 MLD IG that existed downstream. Based on the 2016 monthly report, the river supplied $43 \%$, and 29 deep wells supplied $57 \%$ of the water requirement of the service area. Water shortage is experienced during summer, when tourist arrivals peaks and little precipitation is expected, leading to an increased reliance on groundwater supply. Saltwater intrusion has already been observed in one of the wells managed by the Puerto Princesa City Water District (PPCWD) (based on an interview with the PPCWD). This has led to a proposal to develop a new surface-water source, the Lapu-Lapu watershed, to better meet the current and future water demands.

The Puerto Princesa City (PPC) municipality encompasses a total land area of approximately $220,000 \mathrm{ha}, 70 \%$ of which is covered by forests. The topography is mainly hilly to mountainous $(65 \%)$, where only $35 \%$ of the land is close to sea level or has a gently sloping terrain. The region is influenced by a tropical monsoon climate, which is characterized by a short dry season, followed by several months of heavy rainfall. The average annual rainfall is $1553 \mathrm{~mm}$. The highest and lowest recorded rainfall were $2594 \mathrm{~mm}$ in 1999 and $986 \mathrm{~mm}$ in 1991, respectively. The daily average minimum and maximum temperatures are $24.7^{\circ} \mathrm{C}$ and $32.6^{\circ} \mathrm{C}$, respectively.

At present, the primary water system of the PPCWD is limited to the service area where $77 \%$ (or 196,119) of the population is concentrated and where middle-high-income groups are typically found. This is partly explained by the group's ability to pay, which shapes the extension and improvement of the water system, and the potential demand from socioeconomic activities in the area. As of 2015, only $74 \%$ of the households in the service area were metered, and this is projected to increase as the population and income increase, and as the resilience of the water supply to adverse changes improves.

\section{Data and Methods}

This study involves three steps: (1) assessment and projection of water availability and water demand, (2) model calibration and evaluation, and (3) integrated scenario analyses. The hydrometeorological output of the Soil and Water Assessment Tool (SWAT v.12, developed and supplied by the United States Department of Agricultural Research Service at the Blackland Research \& Extension Center in Temple, Texas, USA) was used to determine water availability [21]. Water demand was classified as domestic, commercial, institutional, and tourism based on population and tourist arrivals. The accuracy of the predicted water yield was evaluated using the Nash-Sutcliffe efficiency (NSE) and coefficient of determination $\left(\mathrm{R}^{2}\right)$, and the projections of the demand models were determined using the mean absolute percentage error (MAPE). In step (3), the potential of surface-water supply, that is, sufficiency or deficiency, was assessed for the three scenarios. 


\subsection{Water Availability}

The surface water available at three watersheds (Irawan, Lapu-Lapu, and Montible) was determined using the SWAT model [21-23] and computed using Equation (1). Watersheds were subdivided into subbasins using a river network map (Figure 3). Despite the sudden increase in tourist arrivals since 2009, the assumptions for planning and designing water-supply systems have remained unchanged, thereby ignoring the changing water consumption patterns. Sub-basins were then further divided into hydrological response units, which consist of large areas with unique combinations of soil, land use, and slope.

$$
\mathrm{SW}_{\mathrm{t}}=\mathrm{SW}_{0}+\sum_{\mathrm{i}=1}^{\mathrm{t}}\left(\mathrm{R}_{\text {day }}-\mathrm{Q}_{\text {surf }}-\mathrm{E}_{\mathrm{a}}-\mathrm{W}_{\text {seep }}-\mathrm{Q}_{\mathrm{gw}}\right)
$$

where $\mathrm{SW}_{\mathrm{t}}$ and $\mathrm{SW}_{0}$ indicate the final and initial soil water contents, respectively, $\mathrm{t}$ is the time (days), $R_{\text {day }}$ is the precipitation, $Q_{\text {surf }}$ is the surface runoff, $E_{a}$ is the evapotranspiration, $\mathrm{w}_{\text {seep }}$ is the water entering the vadose zone from the soil profile, and $\mathrm{Q}_{\mathrm{gw}}$ is the return flow. The unit of all parameters is $\mathrm{mm}$, and i represents the parameter value for a day.

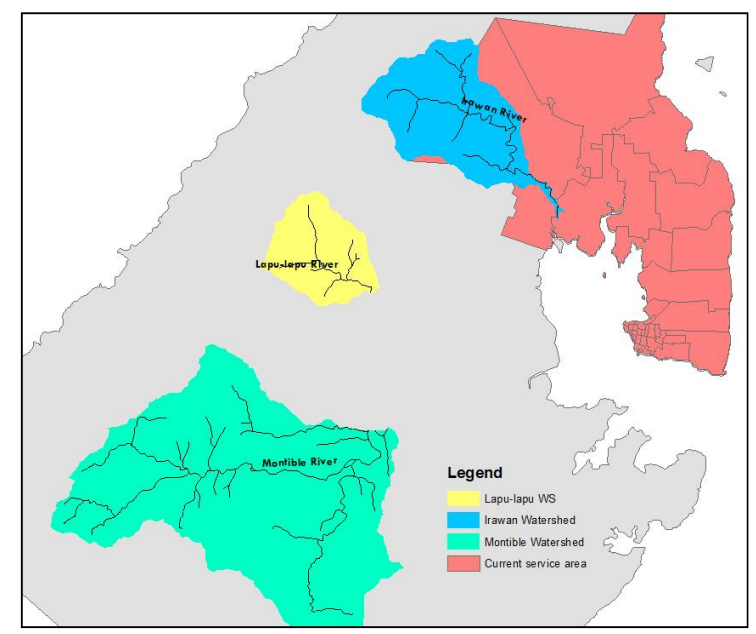

Figure 3. Current service area and river network map of Irawan, Lapu-Lapu, and Montible watersheds.

Baseline (1980-2017) daily rainfall, relative humidity, and temperature obtained from the Philippine Atmospheric Geophysical and Astronomical Services Administration's (PAGASA) Puerto Princesa Synoptic Station were used. The study region has only one weather station that is situated approximately $13 \mathrm{~km}$ away from the Irawan watershed (WS) and $21 \mathrm{~km}$ from the Montible WS. The future climate data obtained from the simulations of the Hadley Center Global Environment Model2-Earth System (HaDGEM2-ES) global climate model, were subjected to bias correction through the intersectoral impact model intercomparison project-fast track (ISIMIP-FT) framework [24,25], and four representative concentration pathways (RCPs) such as RCP2.6, RCP4.5, RCP6.0, and RCP8.5 were used. Additional and equally essential input data are listed in Table A1.

The first five years of the baseline and future simulations (1980-1984 and 2015-2019, respectively) were used as warm-up periods. Note that the data used for calibration (1980-1990) and validation (1991-1999) were generated using a water balance approach based on the actual observations of Pennoni et al. (2002) [26]. On the other hand, the Lapu-Lapu WS was neither validated nor calibrated due to a lack of data. The calibrated parameters from the Irawan WS were simply transferred because of its proximity and comparable topography, soil, and land use.

Automatic calibration, validation, and uncertainty analyses were performed using the sequential uncertainty fitting algorithm version 2 (SUFI-2) in the SWAT calibration and uncertainty programs package [27]. The model was evaluated using monthly discharge 
by computing $\mathrm{R}^{2}$ and NSE values [28]. The suggested statistical thresholds are shown in Table 1.

Table 1. Statistical thresholds for model evaluation and calibration [28].

\begin{tabular}{cc}
\hline Objective Function & Threshold (Streamflow) \\
\hline NSE & \\
Very good & $0.75-1.00$ \\
Good & $0.65-0.75$ \\
Satisfactory & $0.50-0.65$ \\
Unsatisfactory & $\leq 0.50$ \\
$\mathrm{R}^{2}$ & $\geq 0.50$ \\
T-stat & Larger absolute value \\
$p$-value & $<0.05$ \\
\hline
\end{tabular}

In the absence of clear standards for setting EF in the Philippines, this study adopted a presumptive standard that allowed up to $20 \%$ of annual and monthly flows for alteration, maintaining $80 \%$ of flows to sustain ecological health [29].

\subsection{Water Demand}

Population is the primary data used for determining conventional municipal water demand (domestic, commercial, and institutional demand sectors) in a service area [30]. This was projected geometrically from the 2015 census. The projected municipal growth rates used were computed using the ratio method from the projected provincial growth rates until 2045 obtained from the Philippines Statistics Authority. The absence of longer projected growth rates enabled us to use the 2045 growth rate until 2100 projections [31,32].

A stylized model [33] (Equation (2)) was used to capture the tourism sector's water demand (corresponding to the business as usual (BAU) scenario) and to determine the total municipal demand. Each demand type was determined using Equations (2a)-(2g). Commercial and institutional consumers were determined proportionally to the population [30]. All water-use factors (WFs) were determined from consumption records. The lack of water consumption records for the year 2000 and before limited the validation to focus on demand Scenario 2 (BAU scenario) only.

$$
\operatorname{TotD}_{\mathrm{t}}=\mathrm{DD}_{\mathrm{t}}+\mathrm{CD}_{\mathrm{t}}+\mathrm{ID}_{\mathrm{t}}+\mathrm{TD}_{\mathrm{t}}
$$

where $\operatorname{Tot}_{t}$ is the total water demand in the service area per unit time $t\left(\mathrm{~m}^{3} / \mathrm{t}\right), \mathrm{DD}_{t}$ is the domestic demand in the service area per unit time $t\left(\mathrm{~m}^{3} / \mathrm{t}\right), \mathrm{CD}_{\mathrm{t}}$ is the commercial demand in the service area per unit time $t\left(\mathrm{~m}^{3} / \mathrm{t}\right), \mathrm{ID}_{\mathrm{t}}$ is the institutional demand in the service area per unit time $t\left(\mathrm{~m}^{3} / \mathrm{t}\right)$, and $\mathrm{TD}_{\mathrm{t}}$ is the tourism demand in the service area per unit time $\mathrm{t}\left(\mathrm{m}^{3} / \mathrm{t}\right)$.

Domestic demand $\left(\mathrm{DD}_{\mathrm{t}}\right)$ is the utilization of water directly drawn from a source or supply system by a household for drinking, washing, bathing, cooking, and watering of gardens, or by animals and other domestic uses. Thus, it is entirely driven by the population and calculated using Equation (2a) [30].

$$
\mathrm{DD}_{\mathrm{t}}=\mathrm{P}_{\mathrm{t}} \times \mathrm{DWF}_{\mathrm{t}}
$$

where $\mathrm{DD}_{t}$ is the domestic demand per unit time $t, \mathrm{P}_{t}$ is the population per unit time $t$, and $\mathrm{DWF}_{t}$ is the domestic water use factor per unit time $t$. A provincial-level projected population growth until the year 2045 was obtained from the Philippine Statistics Authority (PSA), which accounts for the demographic changes occurring in each province, such as fertility, mortality, and migration. These data absent at the municipal/city level, making it impossible to use such a method. Alternatively, the population was projected using a geometric Equation (2b) by utilizing population growth rates [30]. The projected municipal growth rates were calculated using the ratio method [31,32] to that of the projected 
provincial growth rates from the PSA until 2045. Constant growth rates were applied for succeeding years, which is equal to the last projected growth rate (2045). The initial population was based on the 2015 census population.

$$
\mathrm{P}_{\mathrm{t}}=\mathrm{P}_{0}\left(1+\frac{\mathrm{r}}{100}\right)^{\mathrm{t}}
$$

It is assumed that services cover $90 \%$ of the $74 \%$ population within the city in 2015 (74\% of the households in 2015 resided within the service area; based on interviews with water company managers), and the services will be expanded to neighboring villages. The DWF was calculated as $152 \mathrm{~L}$ per capita per day (lcpd), or $0.152 \mathrm{~m}^{3}$ day $^{-1}$, based on the 2016 consumption records of the PPCWD. According to the Local Water Utilities Administration (LWUA) [31], this value is projected to increase by $5 \%$ every five years.

Commercial water demand $\left(\mathrm{CD}_{\mathrm{t}}\right)$ includes all other private businesses and industries. It is determined by the number of commercial connections that can be derived from the ratio of commercial establishments to the population in the service area [30]. There is a relationship between the number of commercial-industrial connections and the service area population, which varies between 0.3 and 1.2 connections per 100 population [31]. Based on the 2016 records of the PPCWD, a ratio of 0.36 commercial connections per 100 inhabitants (excluding accommodation establishments (AEs)) was used. The commercial connections could then be used to assess the commercial water demand using Equation $(2 \mathrm{c}, \mathrm{d})$ as follows:

$$
\mathrm{CD}_{\mathrm{t}}=\mathrm{C}_{\mathrm{t}} \times \mathrm{CWF}_{\mathrm{t}}
$$

where $\mathrm{CWF}_{\mathrm{t}}$ is the commercial water use factor per unit time, $\mathrm{t}$. The $\mathrm{CWF}_{\mathrm{t}}$ is benchmarked in the year 2000 records and projected to increase by $2 \%$ annually. This year is the earliest consumption record collected, which was when the effect of tourism on commercial water consumption was still negligible (i.e., $0.17 \%$ of the population comprises daily tourists). The $2015 \mathrm{CWF}$ was determined as $1.9 \mathrm{~m}^{3} \mathrm{conn}^{-1}$ day $^{-1}$, and this value was used to predict the succeeding years with a $5 \%$ increase every 5 years [31].

$$
\mathrm{C}_{\mathrm{t}}=\frac{\mathrm{P}_{\mathrm{t}}}{100} \times 0.36
$$

where $C_{t}$ is the number of commercial connections per unit time $t, P_{t}$ is the population per unit time $t$, and $C_{t}$ is the commercial demand per unit time $t$.

The institutional water demand $\left(\mathrm{ID}_{\mathrm{t}}\right)$ includes water requirements from schools, churches, public administration buildings, and hospitals, and it was calculated using Equations $(2 \mathrm{e}, \mathrm{f})$. The underlying assumption is that there is one institutional connection per 2000 inhabitants. Based on the PPCWD 2016 records, the calculated IWF is $13.41 \mathrm{~m}^{3}$ day $^{-1}$ connection $^{-1}$ and it is projected to increase by $2.6 \%$ every 5 years [31].

$$
\begin{gathered}
\mathrm{ID}_{\mathrm{t}}=\mathrm{I}_{\mathrm{t}} \times \mathrm{IWF}_{\mathrm{t}} \\
\mathrm{I}_{\mathrm{t}}=\frac{\mathrm{P}_{\mathrm{t}}}{2000}
\end{gathered}
$$

where $I_{t}$ is the number of institutional connections per unit time $t, P_{t}$ is the population per unit time $t, I D_{t}$ is the institutional demand per unit time $t$, and $I N F_{t}$ is the institutional WF per unit time $t$.

Tourism water demand $\left(\mathrm{TD}_{t}\right)$ is the consumption determined from AEs [11,12,15,34,35]. There are significant differences in water consumption depending on the type of accommodation (hotel, campsites, bed and breakfast, resort, etc.) and tourist activities. This study adopted the City Tourism Office's (CTO) AE classification (hotels, tourist inns, pension houses, and resorts). The monthly water consumption was determined from a purposive stratified sample of 82 AEs within the service area based on the 2017 PPCWD records. Based on the CTO's report, the average overnight stay period per tourist per AE type is 1.6 nights (the average length of stay of a tourist in the city per visit). The average tourist 
water consumption factor $\left(\mathrm{TWF}_{\mathrm{j}}\right)$ at each AE type per tourist per overnight stay was then computed using a simple arithmetic mean (Equation (2h)). This value was held constant throughout the forecast period because the literature on variations in tourist water consumption was not available. The monthly and annual water consumptions were computed using Equation (2g) as follows:

$$
\begin{array}{r}
\mathrm{TD}_{\mathrm{t}}=\mathrm{F}_{\mathrm{t}} \times 1.6 \times \mathrm{TWF}_{\mathrm{j}} \\
\mathrm{TWF}_{\mathrm{j}}=\sum_{\mathrm{i}=1}^{\mathrm{n}} \mathrm{a}_{\mathrm{i}}, \mathrm{a}=\frac{\mathrm{WC}_{\mathrm{jt}}}{\mathrm{TOS}_{\mathrm{jt}}}
\end{array}
$$

where $\mathrm{TD}_{\mathrm{t}}$ is the tourism water demand per unit time $\mathrm{t}, \mathrm{F}$ is the predicted number of tourists at time $t, \mathrm{TWF}_{\mathrm{j}}$ is the tourism water consumption factor, $\mathrm{j}$ is the AE type, $\mathrm{n}$ is the total number of samples, and $a$ is the water consumption at time $t\left(\mathrm{WC}_{\mathrm{jt}}\right)$ divided by the total number of guest night stays at time $t\left(\mathrm{TOS}_{\mathrm{jt}}\right)$ of each accommodation.

Tourist arrivals simulation (Equation. (3)) was first calibrated and validated using the Holt-Winters exponential smoothing curve [36] fitted to the observed monthly tourist arrivals from 2005 to 2017. A fitted curve was used to predict future tourist arrivals. The average overnight stay was determined from sampled AE occupancy records. It was then added to the conventional total simulated municipal demand and subjected to validation.

$$
\begin{gathered}
\mathrm{F}_{\mathrm{t}+\mathrm{m}}=\left(\mathrm{S}_{\mathrm{t}}+\mathrm{mb} \mathrm{b}_{\mathrm{t}}\right) \mathrm{I}_{\mathrm{t}-\mathrm{L}+\mathrm{m}} \\
\mathrm{S}_{\mathrm{t}}=\alpha \frac{\mathrm{y}_{\mathrm{t}}}{\mathrm{I}_{\mathrm{t}-\mathrm{L}}}+(1-\alpha)\left(\mathrm{S}_{\mathrm{t}-1}+\mathrm{b}_{\mathrm{t}-1}\right) \\
\mathrm{b}_{\mathrm{t}}=\gamma\left(\mathrm{S}_{\mathrm{t}}-\mathrm{S}_{\mathrm{t}-1}\right)+(1-\gamma) \mathrm{b}_{\mathrm{t}-1} \\
\mathrm{I}_{\mathrm{t}}=\beta \frac{\mathrm{y}_{\mathrm{t}}}{\mathrm{S}_{\mathrm{t}}}+(1-\beta) \mathrm{I}_{\mathrm{t}-\mathrm{L}}
\end{gathered}
$$

where $y_{t}$ denotes the actual observation, $S_{t}$ is the smoothed observation, $b_{t}$ is the trend factor, $I_{t}$ is the seasonal smoothing, $F_{t+m}$ is the forecast at $m$ periods ahead, $t$ is an index denoting a time period, $L$ refers to the number of data points that indicate the beginning of a new season, and $\alpha, \beta$, and $\gamma$ are constant values between 0 and 1 that must be estimated such that the error is minimized.

\subsection{Integrated Supply and Demand Scenarios}

Three possible scenarios, accounting for future population, climate, and tourism, were developed to assess the dynamics between water demand and supply (Table 2). Water

\begin{tabular}{|c|c|c|}
\hline & Demand Scenario & Supply Scenario \\
\hline Scenario 1 & $\begin{array}{l}\text { Municipal Demand (Population, } \\
\text { commercial, and institutional demand) }\end{array}$ & $\begin{array}{c}\text { Irawan WS + Climate Change + } \\
\text { with and without EFR }\end{array}$ \\
\hline Scenario 2 & Municipal Demand + Tourism (BAU) & $\begin{array}{c}\text { Irawan WS + Lapu-Lapu WS + } \\
\text { Climate Change + with and } \\
\text { without EFR }\end{array}$ \\
\hline Scenario 3 & $\begin{array}{l}\text { BAU + Tourism + Service area expansion } \\
\quad \text { (increased municipal demand) }\end{array}$ & $\begin{array}{c}\text { Irawan WS + Lapu-Lapu WS + } \\
\text { Montible WS + Climate Change + } \\
\text { with and without EFR }\end{array}$ \\
\hline
\end{tabular}
demand is driven by changes in the population and tourist arrivals over time. On the other hand, water supply is determined based on the simulated water yield from the current (Irawan WS) and additional surface-water sources (Lapu-Lapu WS and/or Montible WS) while maintaining or ignoring EF regulation (EFR).

Table 2. Integrated demand and supply scenarios.

$\overline{\mathrm{WS}}$ = watershed; BAU = business as usual; EFR = environmental flow regulation. 
To determine the level of water scarcity, water demand was compared with water availability on an annual and monthly basis [37]. The city was judged as surface-water sufficient (SWS) when the forecasted water supply exceeded the forecasted demand (demand < supply). Conversely, the city was judged as surface-water deficient (SWD) when the forecasted demand exceeded the forecasted supply (demand > supply).

\section{Results and Discussion}

\subsection{Model Calibration and Sensitivity Analysis}

Model evaluation yielded highly adequate results in the Irawan WS (NSE $=0.87$, $\mathrm{R} 2=0.88$ ) and Montible WS (NSE = 0.88, R2 = 0.84, "Very Good (see Table 1)") showing less error variance between the simulated and measured data. The Irawan WS was calibrated with eight parameters of high sensitivity (Table A2) that belong to soil, groundwater, evapotranspiration and time of concentration, surface runoff, and channel processes. The Montible WS, on the other hand, was calibrated with seven parameters of high sensitivity (Table A2) that belong to soil and groundwater processes, channel processes, and evapotranspiration.

Neither measured nor simulated discharge data were available for the Lapu-Lapu WS. Similarities to the Irawan WS based on land cover, soil type, and topography were observed. Thus, the sensitive parameters for the Irawan WS were used in calibrating the Lapu-Lapu WS.

\subsection{Water Availability Considering Climate Change and Environmental Flow}

The annual average minimum and maximum temperatures will decrease in RCP2.6 and increase in other RCPs, compared to the baseline (Table 3). Dry months (February to April) will continue to be dry (driest in April), while the wet season will be wetter in all watersheds (wettest from October to December; see Figure 4). The projected increase in rainfall occurs during the wettest months, during which extreme rainfall events typically occur, which is consistent with global and regional studies [38,39]. Evapotranspiration is highest during the wet season and lowest in the dry season in all of the three WSs possibly because the wet season offers enough soil moisture so that plants can transpire close to their potential rate. Eventually, ET will reduce due to a shortage of water during the dry season; then, soil moisture is consumed [40].

Table 3. Annual mean of historical and projected climate variables.

\begin{tabular}{cccccc}
\hline & Baseline & RCP2.6 & RCP4.5 & RCP6.0 & RCP8.5 \\
\hline Rainfall (mm) & 1549.0 & 1734.0 & 1756.0 & 1708.0 & 1781.0 \\
Min. Temperature $\left({ }^{\circ} \mathbf{C}\right)$ & 24.7 & 24.6 & 25.0 & 33.0 & 33.8 \\
Max. Temperature $\left({ }^{\circ} \mathbf{C}\right)$ & 32.6 & 32.4 & 32.8 & 33.0 & 33.8 \\
Relative Humidity $(\%)$ & 74.0 & 72.0 & 72.0 & 83.0 & 72.0 \\
\hline
\end{tabular}

The annual water yield is projected to increase for all RCPs in the three WSs possibly because of the projected increase in rainfall. The water yield increase was significant for all RCPs in the Irawan WS; in RCP2.6, and RCP6.0 in the Lapu-Lapu WS, and RCP2.6, RCP6.0, and RCP8.5 in the Montible WS (Table 4). A large fraction of the water yield originates from the baseflow (lateral + return flow), with minimal contribution from surface runoff (Figure 4). This is pronounced in the Montible WS, which is also less affected by seasonality, indicating a reliable water source in the present condition and in the future. This is possibly due to the fact that the Montible WS has a larger drainage area with less rugged terrain; hence, it has a higher potential for storing water for baseflow. During the dry months, the projected increase in the mean monthly water yield in the Montible WS was relatively stable up to April, compared to the Irawan and Lapu-Lapu WSs, where it occurred only until February (Figure 4b). Likewise, baseflow was highest in the wet season and lowest during the dry season (March-May) in all WSs (Figure 4c). 
(a) Monthly Average Evapotranspiration ( $\mathrm{mm}$ )
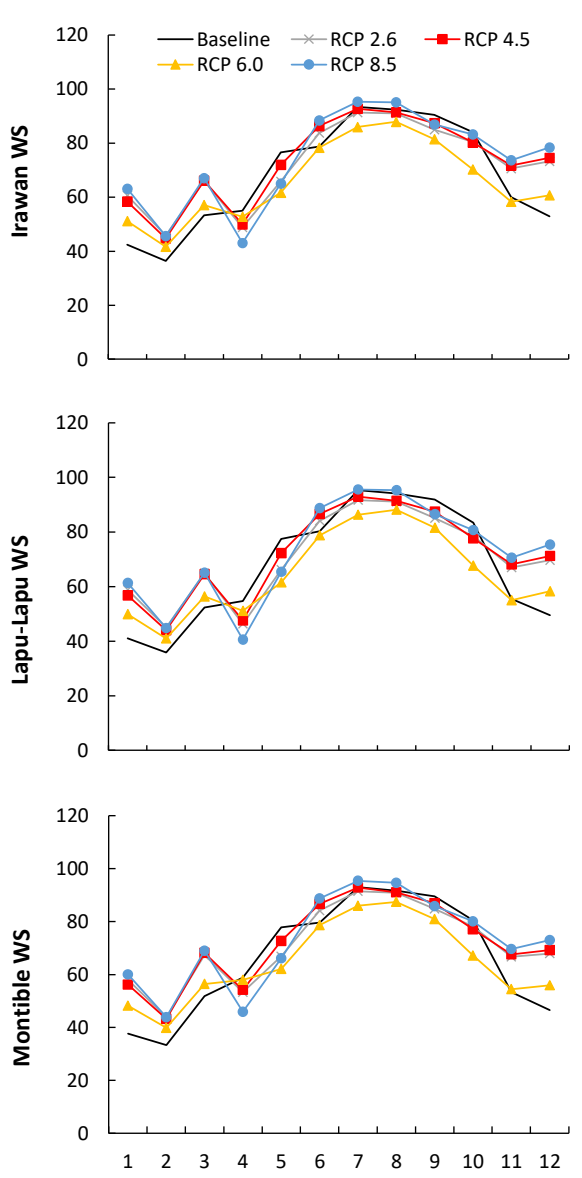

(b) Monthly Average Water Yield (mm)
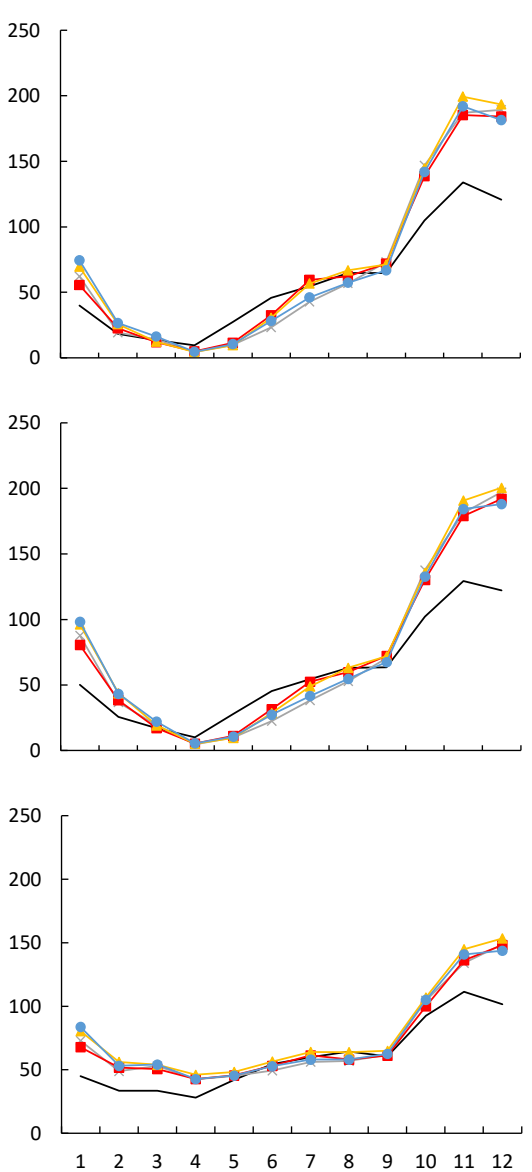

(c) Monthly Average Surface Runoff (mm)
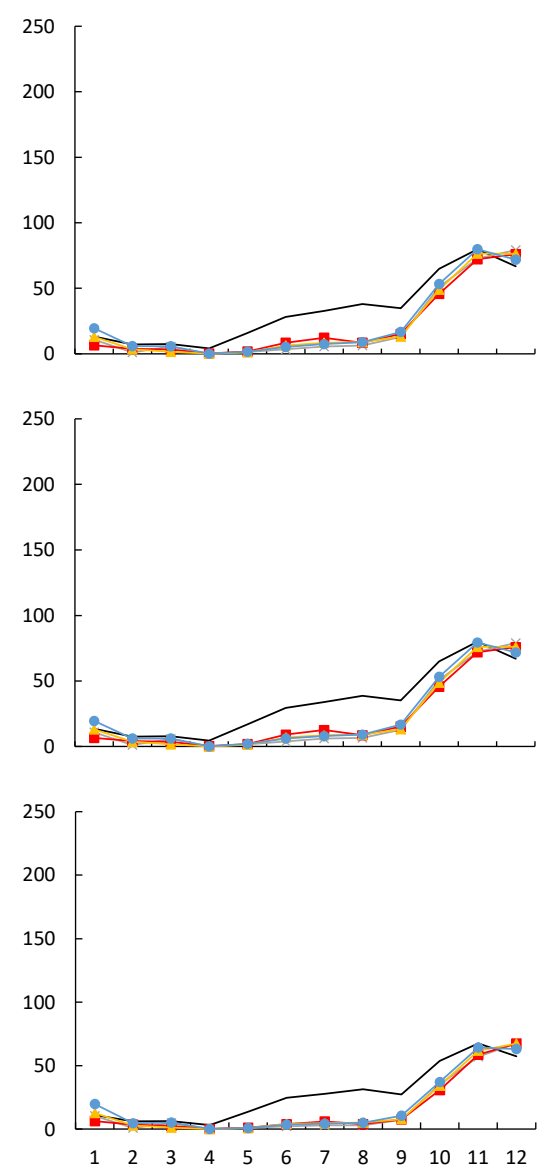

Figure 4. Seasonal trend and changes between baseline (1980-2017) and projected (2020-2100) evapotranspiration, water yield, and surface runoff in each watershed and representative concentration pathways (RCP2.6, RCP4.5, RCP6.0, and RCP8.5).

Table 4. Results of chi-square test of water yield in the target watersheds and RCPs. The significant threshold for the $p$-value is less than 0.05 . The filled-in boxes are nonsignificant values.

\begin{tabular}{ccccc}
\hline \multirow{2}{*}{ Watershed } & \multicolumn{4}{c}{$p$-Value (Significance < 0.05) } \\
\cline { 2 - 5 } & $\mathbf{R C P 2 . 6}$ & $\mathbf{R C P 4 . 5}$ & $\mathbf{R C P 6 . 0}$ & $\mathbf{R C P 8 . 5}$ \\
\hline Irawan WS & 0.002 & 0.007 & 0.000 & 0.024 \\
Lapu-Lapu WS & 0.007 & 0.124 & 0.027 & 0.071 \\
Montible WS & 0.011 & 0.059 & 0.005 & 0.016 \\
\hline
\end{tabular}

The potential water availability increases with climate change. However, to maintain EFR, the annual average water availability dramatically decreases by $80 \%$ at $3.78-4.83 \mathrm{Mm}^{3}$ in Scenario 1, 6.40-8.20 $\mathrm{Mm}^{3}$ in Scenario 2, and 23.31-30.13 $\mathrm{Mm}^{3}$ in Scenario 3 (Table 5). As a result, for Scenarios 1 and 2, the dependency on groundwater will remain inevitable in the immediate future.

\subsection{Social Changes and Water Availability}

The estimate of tourist arrivals achieved through simulation is rather accurate (MAPE $=7.7 \%$ ) and was used to validate the stylized model for demand Scenario 2 (where MAPE is $5.7 \%$ ). Tourist arrivals are likely to increase as the municipality expands its connectivity to other major islands in the country and to other countries. Along with this, water demand is also expected to skyrocket and potentially compete with the domestic 
water demand. In 2016, the water demand of a tourist for a one-night stay was equivalent to the water demand of three locals per day (Figure 5). Note that tourist water use is rather underestimated as hotels rely heavily on private wells for supply and do not disclose the amount of water pumped. Therefore, $8 \%$ of the projected societal demand is from tourists and this is projected to increase to $13 \%$ by 2100 . Moreover, the expansion of the service area will account for $10 \%$ of the projected societal demand during the entire projection period, as illustrated in Figure 6.

Table 5. Annual water yield for each supply scenario.

\begin{tabular}{|c|c|c|c|c|c|c|c|c|c|c|}
\hline \multirow{2}{*}{$\begin{array}{c}\text { Watershed } \\
\text { Source }\end{array}$} & \multicolumn{5}{|c|}{ Without EFR } & \multicolumn{5}{|c|}{ With EFR } \\
\hline & Baseline & RCP 2.6 & RCP 4.5 & RCP 6.0 & RCP 8.5 & Baseline & RCP 2.6 & RCP 4.5 & RCP 6.0 & RCP 8.5 \\
\hline \multicolumn{11}{|c|}{ Supply Scenario 1: Irawan WS } \\
\hline Mean & 18.87 & 22.66 & 22.95 & 24.16 & 23.09 & 3.78 & 4.53 & 4.59 & 4.83 & 4.62 \\
\hline Minimum & 6.33 & 2.49 & 8.71 & 11.95 & 8.35 & 1.27 & 0.50 & 1.74 & 2.39 & 1.67 \\
\hline Maximum & 44.06 & 39.74 & 57.87 & 46.39 & 52.10 & 8.81 & 7.95 & 11.57 & 9.28 & 10.42 \\
\hline \multicolumn{11}{|c|}{ Supply Scenario 2: Irawan + Lapu-Lapu WS } \\
\hline Mean & 31.98 & 38.49 & 39.00 & 41.02 & 39.24 & 6.40 & 7.70 & 7.80 & 8.20 & 7.85 \\
\hline Minimum & 10.72 & 4.94 & 15.49 & 20.33 & 14.42 & 2.14 & 0.99 & 3.10 & 4.07 & 2.88 \\
\hline Maximum & 74.72 & 66.29 & 98.01 & 78.55 & 89.12 & 14.94 & 13.26 & 19.60 & 15.71 & 17.82 \\
\hline \multicolumn{11}{|c|}{ Supply Scenario 3: Irawan + Lapu-Lapu + Montible WS } \\
\hline Mean & 116.48 & 140.21 & 141.36 & 150.54 & 143.98 & 23.31 & 28.06 & 28.29 & 30.13 & 28.81 \\
\hline Minimum & 46.01 & 54.19 & 83.31 & 98.20 & 74.91 & 9.20 & 10.87 & 16.66 & 19.69 & 14.98 \\
\hline Maximum & 240.88 & 224.00 & 243.89 & 273.07 & 317.91 & 48.18 & 44.80 & 48.78 & 54.76 & 63.58 \\
\hline
\end{tabular}

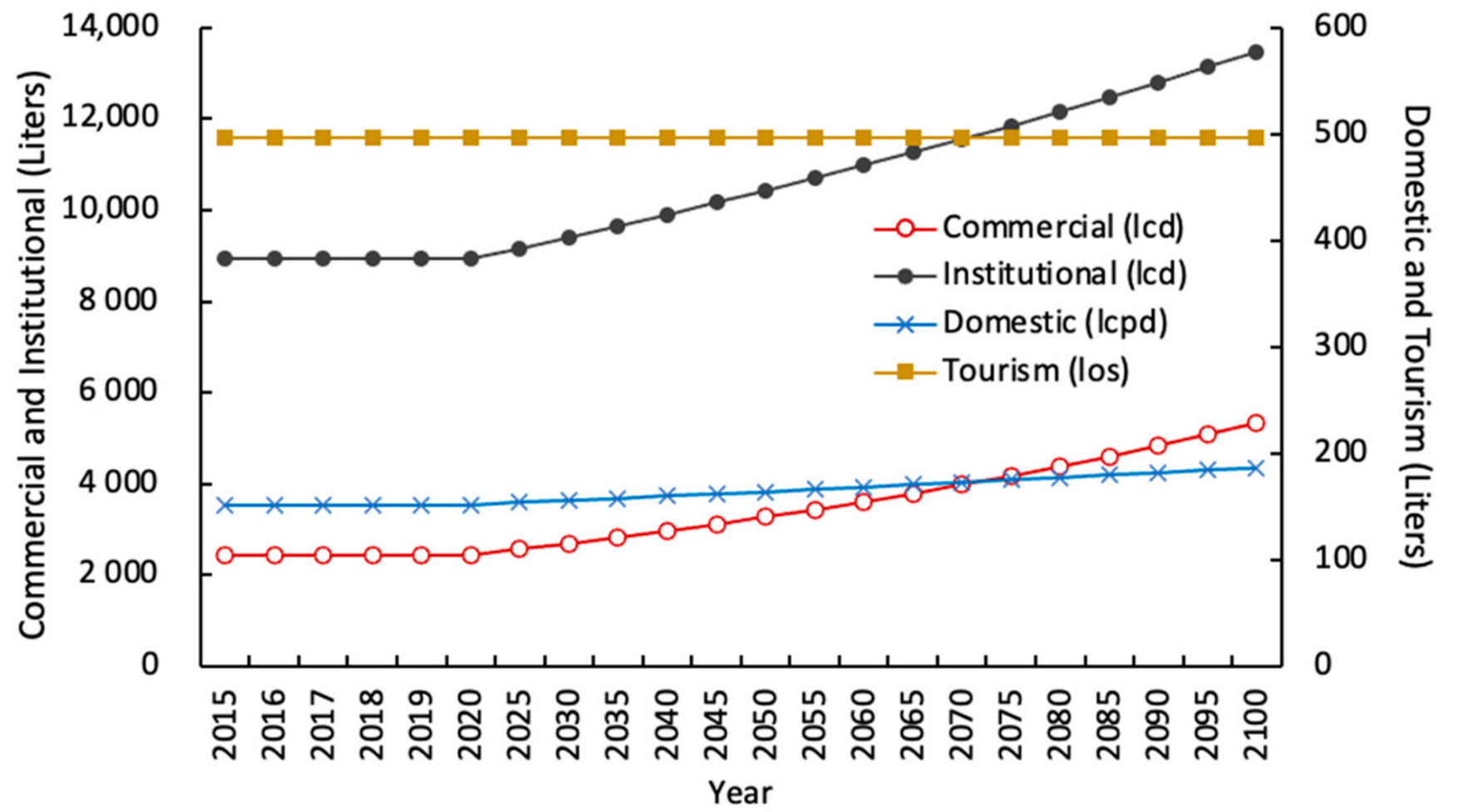

Figure 5. Current (2015) and projected water-use factor projection (in liters). Left vertical axis: commercial and institutional per connection consumption; right vertical axis: domestic and tourist per capita consumption; lcd: liters per connection per day; lcpd: liters per capita per day; los: litters per overnight stay. 
SCENARIO 1

SCENARIO 2

SCENARIO 3

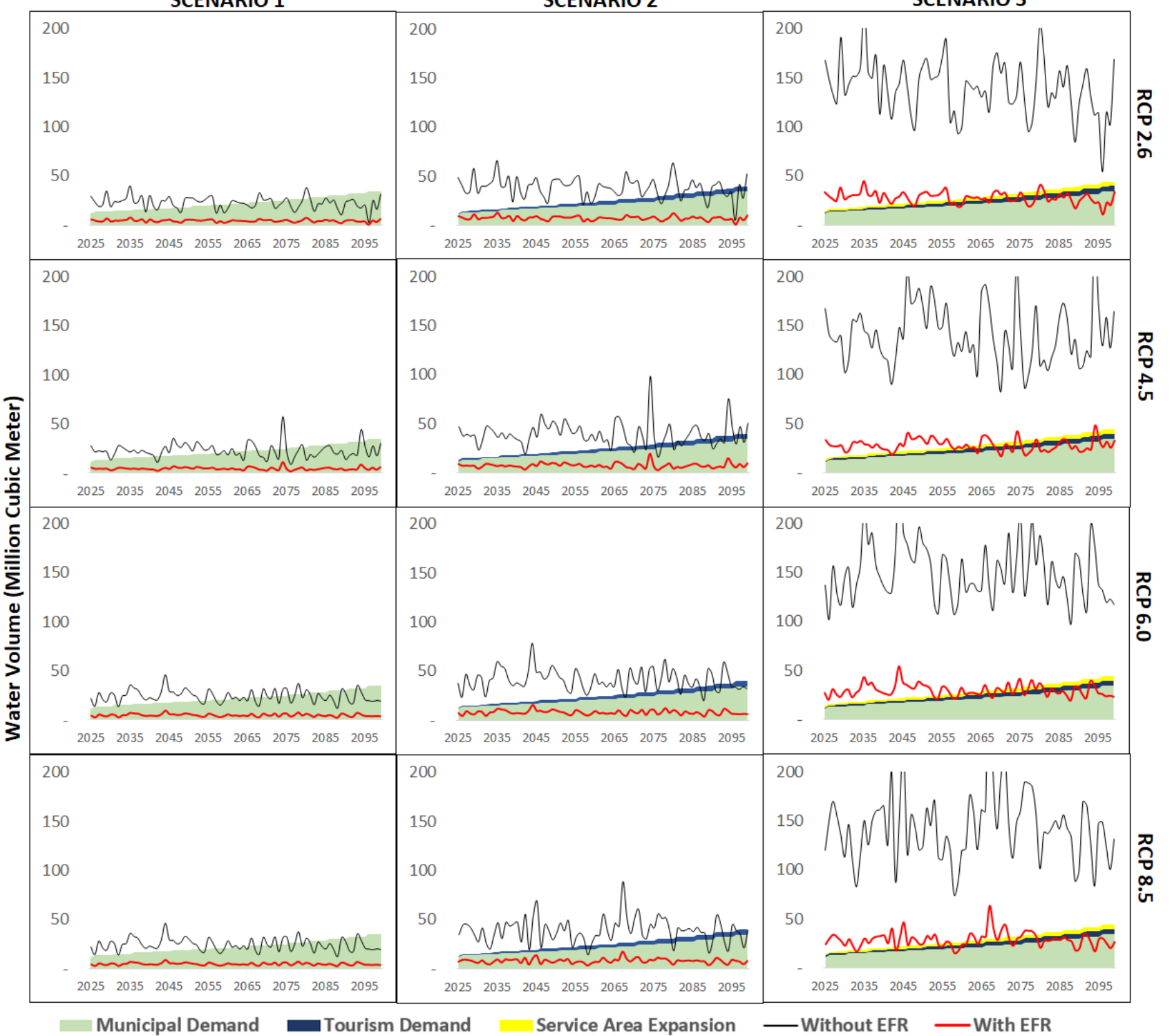

Figure 6. Integrated simulated water availability and forecasted water demand. Disaggregated by scenario (column) for each climate change pathway (row).

\subsection{Integration and Water Availability}

The dynamics of water availability, cumulative changes in society, climate change, and the imposition of EFR are expressed as SWS or SWD throughout the 75-year simulation (Figure 6). When the EFR is maintained, no SWS is possible during the entire simulation period for all scenarios. In addition, SWS is only frequent during the first half of Scenario 3 (53\% of the simulation period). Achieving a sustainable water supply by fulfilling the municipal demand while maintaining the EF can only partly be achieved by the contribution of the Montible WS as a water source. Without EFR, it becomes easier to reach SWS, and the target is met by $48 \%, 83 \%$, and $100 \%$ in Scenarios 1,2, and 3, respectively (Figure 6 and Table 6). Given the current agenda of the PPCWD, despite the planned addition of the Lapu-Lapu WS as an additional surface-water source, the municipality will still suffer from a lack of surface-water supply, and therefore, groundwater will remain a significant contributor to water supply in the service area. 
Table 6. Number of surface-water sufficient (SWS) years during the projection period (2025-2100) for different scenarios.

\begin{tabular}{ccccccccc}
\hline \multirow{2}{*}{ scenario } & \multicolumn{4}{c}{ With EFR } & \multicolumn{5}{c}{ Without EFR } \\
& RCP2.6 & RCP4.5 & RCP6.0 & RCP8.5 & RCP2.6 & RCP4.5 & RCP6.0 & RCP8.5 \\
\hline 1 & 0 & 0 & 0 & 0 & 36 & 36 & 36 & 36 \\
2 & 0 & 0 & 0 & 0 & 64 & 59 & 63 & 65 \\
3 & 39 & 40 & 40 & 40 & 75 & 75 & 75 & 75 \\
\hline
\end{tabular}

The seasonal evolution of the surface water deficit (SWD) is displayed in Figure 7. The larger the web, the longer the municipality will experience SWD. As expected, prominent periods of SWD are concurrent with the dry season (except in Figure 7(3-a)). Considering EFR, SWD will be experienced almost throughout the year in Scenario $1(97 \%)$ and Scenario $2(92 \%)$. In Scenario 3, the SWD is projected from February to September. Without EFR, the SWD decreases to $63 \%, 51 \%$, and $0.01 \%$ for Scenarios 1, 2, and 3, respectively. Again, heavy reliance on groundwater extraction is expected during the SWD months.

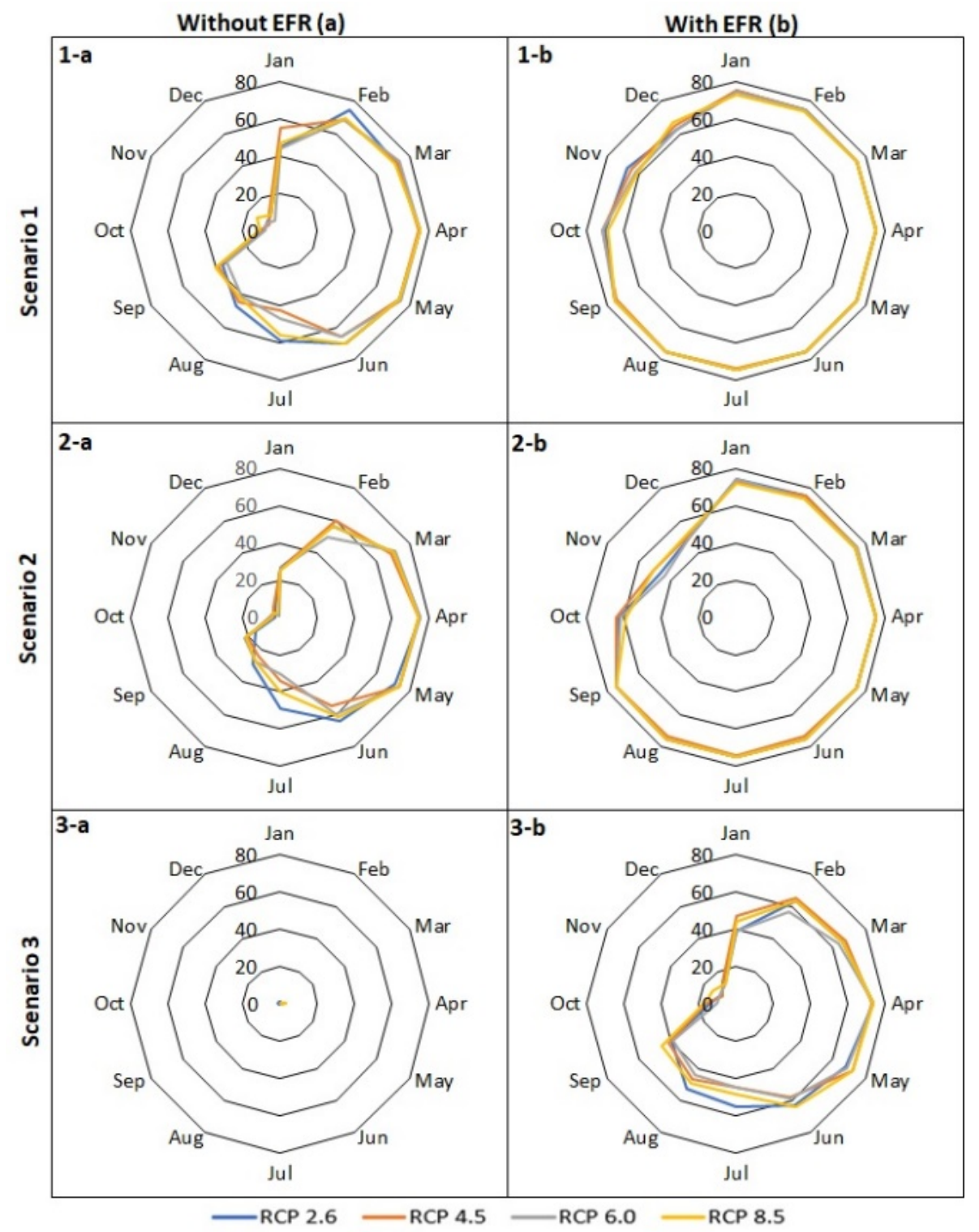

Figure 7. Seasonal surface-water deficit (SWD) in each scenario (Scenario 1-3 and Without EFR (a)/With EFR (b)) in the 75-year projection period (y-axis). 
The need to conduct studies to determine proper EFs for each watershed cannot be overemphasized. EFR refers to (1) recognizing that there is a physical limit beyond which a water resource suffers irreversible damage to its ecosystem functions and (2) systematically balancing the multiple water needs of the society in a transparent and informed manner [41]. This must be determined by science and through social decisions.

\section{Conclusions}

The overall methodology presented in this paper serves as a tool for improving water supply planning practices and updating conventional practices, especially for areas with booming tourism industry. It considers (1) scenarios of seasonal droughts to prepare for climate risks in the future and (2) scenarios of water availability that do not depend on groundwater supply, in which the projected deficiency is frequent both annually and seasonally. For our case study, additional water supply from the Montible WS for the PPC was projected to secure sufficient amounts of water to achieve SWS, which is consistent with the goals of both the municipality and the water company to reduce the dependency on groundwater. Significant investment costs in infrastructure must be anticipated in Scenario 3 because of the proximity to the existing water system.

The proposed integrated approach allows water managers to predict the future of surface-water sufficiency/deficiency in a region with active tourism. It also captures both sustainable and unsustainable options for water development from the perspectives of climate and social changes. Thus, this integrated approach can be used to pursue sustainable water resource development provided that a site-specific EFR is determined. However, there is no panacea for challenges in water-resource planning. Site-specific patterns exist in the consumption and nature of potential water resources. The efficiency of the water distribution system and its effect on water yield may be integrated in future studies for further model improvement.

Author Contributions: Conceptualization, M.A.D.C. and S.N.; methodology, M.A.D.C., J.B., and N.H.; data curation, M.A.D.C.; writing-original draft preparation, M.A.D.C.; writing-review and editing, S.N., J.B., and N.H.; visualization, M.A.D.C.; supervision, S.N.; project administration, S.N.; funding acquisition, S.N. All authors have read and agreed to the published version of the manuscript.

Funding: This study was supported by Grants-in-Aid for Scientific Research (B) from the Japan Society for the Promotion of Science (No. 18H03417) and SATREPS from the Japan Science and Technology Agency and the Japan International Cooperation Agency (No. JPMJSA1909).

Institutional Review Board Statement: Not applicable.

Informed Consent Statement: Not applicable.

Data Availability Statement: Publicly available datasets were analyzed in this study. These data can be found in Appendix A and the cited documents in this article.

Conflicts of Interest: The authors declare no conflict of interest.

Appendix A

Table A1. Input data for ArcSWAT.

\begin{tabular}{ccc}
\hline Data Type & Description & Sources \\
\hline $\begin{array}{c}\text { Digital elevation model } \\
\text { Land use vector }\end{array}$ & $\begin{array}{c}\text { SRTM } 5 \mathrm{~m} \times 5 \mathrm{~m} \text { resolution } \\
\text { Digitized Landsat } 8(30 \mathrm{~m} \times 30 \mathrm{~m})\end{array}$ & $\begin{array}{c}\text { National Mapping and Resource Information } \\
\text { Authority (NAMRIA) (pers.com.) }\end{array}$ \\
Soil vector & Digital Soil Map of the World v. 3.6 (1: & $\begin{array}{c}\text { Land and Water Development Division, FAO, } \\
\text { Rome (http://www.fao.org/geonetwork/ } \\
\text { srv/en /metadata.show } \% \text { Fid }=14116 \\
\text { (accessed on 14 February 2018)) }\end{array}$ \\
\hline
\end{tabular}


Table A1. Cont.

\begin{tabular}{|c|c|c|}
\hline Data Type & Description & Sources \\
\hline Baseline climate data (1980-2017) & $\begin{array}{l}\text { Daily rainfall, relative humidity, } \\
\text { maximum and minimum temperatures } \\
\text { (station point) }\end{array}$ & $\begin{array}{c}\text { Philippine Atmospheric Geophysical and } \\
\text { Astronomical Services Administration } \\
\text { (PAGASA) (pers.com.) }\end{array}$ \\
\hline Climate projection data (2020-2099) & $\begin{array}{l}\text { Bias-corrected daily rainfall, relative } \\
\text { humidity, maximum and minimum } \\
\text { temperatures }\left(0.5^{\circ} \times 0.5^{\circ}\right)\end{array}$ & $\begin{array}{c}\text { HaDGEM2-ES dataset (http:/ / h08.nies.go.jp } \\
\text { and https:/ / esg.pik-potsdam.de (accessed } \\
\text { on } 14 \text { February 2018)) }\end{array}$ \\
\hline Hydrological data (1980-1999) & Monthly streamflow & $\begin{array}{l}\text { Pennoni Associates Inc. et al., } 2002 \\
\text { (pers.com.) }\end{array}$ \\
\hline Weather generator & $\begin{array}{l}\text { Weather generator generated from the } \\
\text { PAGASA observations }\end{array}$ & Alibuyog et al., 2015 (pers.com.) \\
\hline
\end{tabular}

Table A2. Irawan and Montible WS sensitive parameters.

\begin{tabular}{|c|c|c|c|c|c|}
\hline \multirow{2}{*}{ Parameter Name } & \multirow{2}{*}{ Parameter Full Name } & \multicolumn{2}{|c|}{ Irawan WS } & \multicolumn{2}{|c|}{ Montible WS } \\
\hline & & T-Stat & $p$-Value & T-Stat & $p$-Value \\
\hline $\mathrm{R} \_\mathrm{CN} 2 . \mathrm{mgt}$ & SCS curve number & -5.32 & 0.00 & -0.83 & 0.41 \\
\hline R_SOL_K(..).sol & Saturated hydraulic conductivity & 3.95 & 0.00 & -0.49 & 0.63 \\
\hline $\mathrm{R} \_\mathrm{SOL} \_\mathrm{BD}(.$.$) .sol$ & Moist bulk density & -9.63 & 0.00 & -6.51 & 0.00 \\
\hline R_OV_N.hru & Manning's ' $n$ ' value for overland flow & -2.44 & 0.02 & -1.90 & 0.06 \\
\hline V_RCHRG_DP.gw & Deep aquifer percolation fraction & -0.24 & 0.81 & 2.92 & 0.00 \\
\hline V__SURLAG.bsn & Surface runoff lag coefficient & -0.26 & 0.80 & 0.29 & 0.77 \\
\hline V__ALPHA_BF.gw & Baseflow alpha factor & 3.12 & 0.00 & 10.84 & 0.00 \\
\hline V_GW_DELAY.gw & Groundwater delay-time & -0.72 & 0.47 & 2.40 & 0.02 \\
\hline 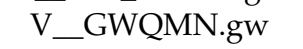 & Groundwater minimum threshold & 0.21 & 0.83 & 0.66 & 0.51 \\
\hline V_GW_REVAP.gw & Groundwater revap coefficient & -0.45 & 0.65 & 0.09 & 0.93 \\
\hline V_ESCO.hru & Soil evaporation compensation factor & -4.28 & 0.00 & -2.71 & 0.01 \\
\hline $\mathrm{V} \_\mathrm{CH}$ _N2.rte & Manning's ' $n$ ' coefficient & -3.06 & 0.00 & -3.09 & 0.00 \\
\hline V_CH_K2.rte & $\begin{array}{l}\text { Effective hydraulic conductivity in the } \\
\text { main alluvium channel }\end{array}$ & -6.96 & 0.00 & -8.45 & 0.00 \\
\hline R_SOL_AWC(..).sol & Available water capacity of the layer soil & -0.22 & 0.82 & 1.34 & 0.18 \\
\hline
\end{tabular}

\section{References}

1. Milly, P.C.D.; Betancourt, J.; Falkenmark, M.; Hirsch, R.M.; Kundzewicz, Z.W.; Lettenmaier, D.P.; Stouffer, R.J. Stationarity Is Dead: Whither Water Management? Science 2008, 319, 573-574. [CrossRef] [PubMed]

2. Oki, T. Global Hydrological Cycles and World Water Resources. Science 2006, 313, 1068-1072. [CrossRef] [PubMed]

3. Savenije, H.H.G.; Hoekstra, A.Y.; Van Der Zaag, P. Evolving water science in the Anthropocene. Hydrol. Earth Syst. Sci. 2014, 18, 319-332. [CrossRef]

4. Sivapalan, M.; Savenije, H.H.G.; Blöschl, G. Socio-hydrology: A new science of people and water. Hydrol. Process. 2012, 26, 1270-1276. [CrossRef]

5. McMillan, H.; Montanari, A.; Cudennec, C.; Savenije, H.; Kreibich, H.; Krueger, T.; Liu, J.; Mejia, A.; Van Loon, A.; Aksoy, H.; et al. Panta Rhei 2013-2015: Global perspectives on hydrology, society and change. Hydrol. Sci. J. 2016, 1-18. [CrossRef]

6. Singh, V.P. Challenges in meeting water security and resilience. Water Int. 2017, 109, 1-11. [CrossRef]

7. Mehran, A.; AghaKouchak, A.; Nakhjiri, N.; Stewardson, M.J.; Peel, M.C.; Phillips, T.J.; Wada, Y.; Ravalico, J.K. Compounding Impacts of Human-Induced Water Stress and Climate Change on Water Availability. Sci. Rep. 2017, 7, 6282. [CrossRef]

8. Maja, M.M.; Ayano, S.F. The Impact of Population Growth on Natural Resources and Farmers' Capacity to Adapt to Climate Change in Low-Income Countries. Earth Syst. Environ. 2021, 1-13. [CrossRef]

9. Becken, S. Water equity-Contrasting tourism water use with that of the local community. Water Resour. Ind. 2014, 7-8, 9-22. [CrossRef]

10. Cole, S. Tourism and water: From stakeholders to rights holders, and what tourism businesses need to do. J. Sustain. Tour. 2013, 22, 89-106. [CrossRef]

11. Gössling, S.; Peeters, P.; Hall, C.M.; Ceron, J.-P.; Dubois, G.; Lehmann, L.V.; Scott, D. Tourism and water use: Supply, demand, and security. An international review. Tour. Manag. 2012, 33, 1-15. [CrossRef]

12. Gössling, S. New performance indicators for water management in tourism. Tour. Manag. 2015, 46, 233-244. [CrossRef]

13. Borobia, M. 5.5 Water and tourismRapporteurs: Monica Borobia, Anne Vourc?h and Egenio Yunis. Participants: 50. Hydrol. Res. 2001, 3, S175-S176. [CrossRef] 
14. Parrilla, J.C.; Font, A.R.; Nadal, J.R. Tourism and long-term growth a Spanish perspective. Ann. Tour. Res. 2007, 34, 709-726. [CrossRef]

15. Tortella, B.D.; Tirado, D. Hotel water consumption at a seasonal mass tourist destination. The case of the island of Mallorca. J. Environ. Manag. 2011, 92, 2568-2579. [CrossRef]

16. Kent, M.; Newnham, R.; Essex, S. Tourism and sustainable water supply in Mallorca: A geographical analysis. Appl. Geogr. 2002, 22, 351-374. [CrossRef]

17. Essex, S.; Kent, M.; Newnham, R. Tourism Development in Mallorca: Is Water Supply a Constraint? J. Sustain. Tour. 2004, 12, 4-28. [CrossRef]

18. Kandasamy, J.; Sounthararajah, D.; Sivabalan, P.; Chanan, A.P.; Vigneswaran, S.; Sivapalan, M. Socio-hydrologic drivers of the pendulum swing between agricultural development and environmental health: A case study from Murrumbidgee River basin, Australia. Hydrol. Earth Syst. Sci. 2014, 18, 1027-1041. [CrossRef]

19. Sood, A.; Smakhtin, V.; Eriyagama, N.; Villholth, K.G.; Liyanage, N.; Wada, Y.; Ebrahim, G.; Dickens, C. Global environmental flow information for the sustainable development goals. In Global Environmental Flow Information for the Sustainable Development Goals; International Water Management Institute (IWMI): Colombo, Sri Lanka, 2017; Volume 168, ISBN 9290908475.

20. PSA. Contribution of Tourism to the Economy is 8.6 Percent in 2016. Phillipines Statistics Authority. 2016. Available online: https:/ / psa.gov.ph/content/contribution-tourism-economy-86-percent-2016. (accessed on 29 September 2019).

21. Neitsch, S.L.; Arnold, J.G.; Kiniry, J.R.; Williams, J.R. Soil and Water Assessment Tool Theoretical Documentation Version 2009; Texas Water Resources Institute: College Station, TX, USA, 2011.

22. Arnold, J.G.; Kiniry, J.R.; Srinivasan, R.; Williams, J.R.; Haney, E.B.; Neitsch, S.L. Soil and Water Assessment Tool Input/Output File Documentation Version 2009; Texas Water Resources Institute: College Station, TX, USA, 2011.

23. Winchell, M.; Srinivasan, R.; Di Luzio, M.; Arnold, J.G. Arcswat Interface for SWAT2012: User's Guide; Blackland Research Center, Texas AgriLife Research, College Station: College Station, TX, USA, 2013; pp. 1-464.

24. Davie, J.C.S.; Falloon, P.D.; Kahana, R.; Dankers, R.; Betts, R.; Portmann, F.T.; Wisser, D.; Clark, D.B.; Ito, A.; Masaki, Y.; et al. Comparing projections of future changes in runoff from hydrological and biome models in ISI-MIP. Earth Syst. Dyn. 2013, 4, 359-374. [CrossRef]

25. Hempel, S.; Frieler, K.; Warszawski, L.; Schewe, J.; Piontek, F. A trend-preserving bias correction-The ISI-MIP approach. Earth Syst. Dyn. 2013, 4, 219-236. [CrossRef]

26. Pennoni Associates Inc.; Knight Piesold Philippines Inc.; Asset \& Infrastructure Partners; Zambrano Associates Law Offices. Pre-Feasibility Studies and Advisory Services for Solicited BOT/Concession Projects for Water Districts. Puerto Princesa City Water District Bulk Water Supply Project: Technical Study; USTDA \& LWUA: Manila, Philippines, 2002.

27. Abbaspour, K.C. SWAT Calibration and Uncertainty Programs-A User Manual; Swiss Federal Institute of Aquatic Science \& Technology (EAWAG): Dübendorf, Switzerland, 2015.

28. Moriasi, D.N.; Arnold, J.G.; Van Liew, M.W.; Bingner, R.L.; Harmel, R.D.; Veith, T.L. Model Evaluation Guidelines for Systematic Quantification of Accuracy in Watershed Simulations. Trans. ASABE 2007, 50, 885-900. [CrossRef]

29. Richter, B.D.; Davis, M.M.; Apse, C.; Konrad, C.P. A Presumptive Standard for Environmental Flow Protection. River Res. Appl. 2011, 28, 1312-1321. [CrossRef]

30. LWUA. Water Supply Feasibility Study Methodology Manual; Local Water Utilities Administration: Quezon City, Phillippines, 1996.

31. LWUA. Water Supply Feasibility Study, Final Report; Local Water Utilities Administration: Quezon City, Philippines, 2007.

32. Zeraebruk, K.N.; Mayabi, A.O.; Gathenya, J.M. Assessment of Water Resources and Analysis of Safe Yield and Reliability of Surface Water Reservoirs of Asmara Water Supply System. Environ. Nat. Resour. Res. 2017, 7, 45. [CrossRef]

33. Srinivasan, V. Reimagining the past-use of counterfactual trajectories in socio-hydrological modelling: The case of Chennai, India. Hydrol. Earth Syst. Sci. 2015, 19, 785-801. [CrossRef]

34. Garcia, C.; Servera, J. Impacts of tourism development on water demand and beach degradation on the island of mallorca (spain). Geogr. Ann. Ser. A. Phys. Geogr. 2003, 85, 287-300. [CrossRef]

35. Dworak, T.; Berglund, M.; Laaser, C.; Strosser, P.; Roussard, J.; Grandmougin, B.; Kossida, M.; Kyriazopoulou, I.; Kolberg, S.; Montesinos Barrios, P. EU Water Saving Potential (Part 1-Report); UNESCO: Berlin, Germany, 2007.

36. Lim, C.; McAleer, M. Forecasting tourist arrivals. Ann. Tour. Res. 2001, 28, 965-977. [CrossRef]

37. Flörke, M.; Schneider, C.; McDonald, R.I. Water competition between cities and agriculture driven by climate change and urban growth. Nat. Sustain. 2018, 1, 51-58. [CrossRef]

38. Stocker, T.F.; Qin, D.; Plattner, G.K.; Tignor, M.; Allen, S.K.; Boschung, J.; Nauels, A.; Xia, Y.; Bex, V.; Midgley, P.M. Summary for Policymakers. In Climate Change 2013: The Physical Science Basis, Contribution of Working Group I to the Fifth Assessment Report of the Intergovernmental Panel on Climate Change; Cambridge University Press: Cambridge, UK, 2013; p. 1535.

39. PAGASA. Observed and Projected Climate Change in the Philippines; Philippine Atmospheric, Geophysical and Astronomical Services Administration: Quezon City, Philippines, 2018; p. 36.

40. De Bruin, H.A.R. Evapotranspiration in Humid Tropical Regions. In Hydrology of Humid Tropical Regions with Particular Reference to the Hydrological Effects of Agriculture and Forestry Practice; UNESCO: Hamburg, Germany, 1983; Volume 140, pp. $299-311$.

41. Hirji, R.; Davis, R. Environmental Flows in Water Resources Policies, Plans, and Projects: Findings and Recommendations; The World Bank: Washington, DC, USA, 2009. 